
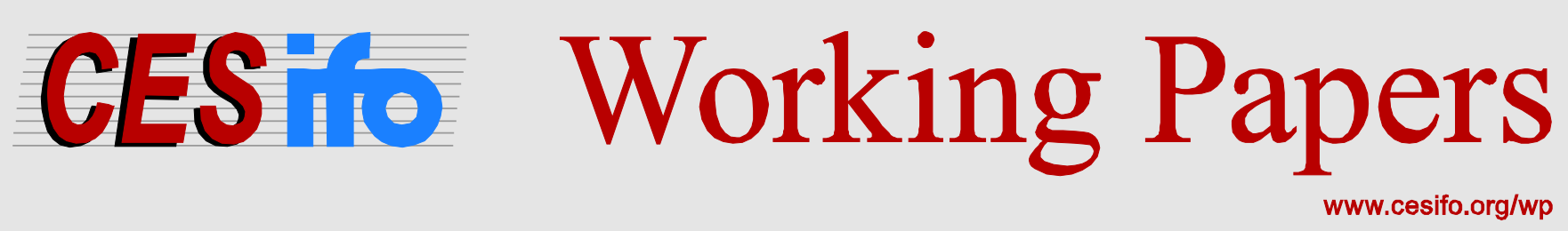

\title{
Taxing Pensions of an Internationally Mobile Labor Force: Portability Issues and Taxation Options
}

\author{
Robert Holzmann
}

CESIFO WORKING PAPER NO. 5715

CATEGory 3: Social Protection

JANUARY 2016

An electronic version of the paper may be downloaded

- from the SSRN website: Www.SSRN.com

- from the RePEc website: Www.RePEc.org

- from the CESifo website: www.CESifo-group.org/wp 


\title{
Taxing Pensions of an Internationally Mobile Labor Force: Portability Issues and Taxation Options
}

\begin{abstract}
There is a rising share of individuals spending at least some part of their working life abroad and acquiring pension rights. While the portability of pensions and other social benefits has received some analytical attention over the recent decade there is currently limited analytical guidance on the taxation of retirement provisions within a country, and there is virtually none for the taxation of internationally portable pensions. For both national and international taxation of pensions, the actual taxation approaches are characterized by a high level of diversity, complexity and inconsistency within and across countries that risk harming labor mobility and creating fiscal unfairness. The proposed taxation approach for internationally portable pensions mixes notional front-loaded taxation (as the tax due on contributions/savings is deferred) with actual backloaded taxation as the taxes are due when the benefits are disbursed (in source or residency country) or when accumulated savings effectively leave the country. This approach promises to establish broadly neutrality for international labor mobility decisions, fiscal fairness of tax revenue around retirement provisions between source and residency country, and bureaucratic efficiency, including a consistency with EU regulations and most double-taxation treaties.
\end{abstract}

JEL-codes: H200, H240, H550.

Keywords: income taxation, cross-border labor mobility, portable pensions, double taxation treaties, EET, TEE, individual and fiscal fairness, bureaucratic effectiveness.

\author{
Robert Holzmann \\ Austrian Academy of Science \\ Vienna / Austria \\ robert.holzmann@gmail.com
}

Final Draft, as of December 29, 2015

Revised paper presented at the 71st Annual Conference of the International Institute of Public Finance on “Taxation in a Global Economy”, Dublin, August 20-23, 2015. A first draft of the paper was presented at the CEPAR \& CESifo Workshop on "Pension Taxation, Population Aging and Globalization" UNSW, Sydney, November 16-17, 2014. The revised paper has profited from comments by workshop and conference participants, the discussant Tina Hausen und intensive discussions with Bernd Genser. 


\section{Introduction}

An increasing number of individuals across the world reside outside their home country, at least for some part of their working life or retirement years. While the absolute numbers of individuals or share in world or EU population that will have resided some period (say at least 6 month) abroad during their life time is not easy to lay hand on, reasonable estimates for the EU population in 2013 puts them between 7 percent and some 25 percent, with rising tendency; a non-negligent magnitude.

While working abroad, these individuals typically acquire rights to social security and employer's benefits that they want take along when moving on, return to their home country or move to their retirement residency, i.e. they expect and want have them made portable else they may reconsider their mobility plan. Among the social benefits the most relevant for migrants are the long-term pension benefits as they present a major share of total wealth of individuals during their life and are critical for life cycle planning. While the portability of public pension benefits among most OECD countries has been more or less established, this is much less the case with countries outside this country group, and portability still faces major issues with occupational and private retirement savings instruments that had received tax privileges during accumulation. Yet even if public and private pensions are made fully portable, another surprise may emerge once retired and in benefit receipt: The pension send from abroad risks being taxable in a complicated manner ranging from not at all to double taxation in both source and residency country. Again, this may impact and distort labor mobility and residency decision while creating undesirable fiscal effects for countries. However, what are the good policies to establish pension portability and fair taxation across countries is a little explored territory and the topic of this paper.

Portability issues of pensions (and health care) benefits have been for a long time the exclusive domain of social lawyers with bilateral social security agreements as the only instruments considered and proposed. The topic received some attention in recent years by economists and some progress in knowledge and conceptualization has been made (see Holzmann et al 2005, Holzmann and Koettl 2015, Holzmann and Werding 2015, and papers in a dedicated 2015 issue of CESifo Economic Studies). As regards the taxation of a mobile labor force the topic remains an almost exclusive domain of international tax lawyers, with double taxation treaties as the only instruments considered and proposed. To shake this dominance and introduce economics into the discussion CEPAR and CEsifo joint forces to explore in two staged workshops the topic of taxation of pensions in general and the taxation of internationally mobile pensions in particular. ${ }^{3}$

To explore the topic, to interest researchers, and to offer initial guidance for policy makers, the structure of this paper is as follows: Section I offers first considerations on the scope of

\footnotetext{
${ }^{3}$ The first workshop was held in Sydney in November 2014 and the second workshop in Munich in early September 2015. All papers and presentation see http://www.cepar.edu.au/publications.aspx and www.cesifogroup.de/ifoHome/events/Archive/conferences/2015/09/2015-09-03-tag15-Holzmann.html; a book production of selected papers is planned for 2016.
} 
individuals concerned by mobility issues and provides some estimates on the share of EU population that may be concerned. Section II summarizes briefly the current understanding of issues, concepts, and implementation challenges associated with the portability of pensions when individuals move between places of work and to their final residency at retirement. Section III presents the perceived key dimensions of complexity that surround the taxation of internationally portable pensions: The complexity and inconsistency of actual taxation approach, and key economic explanations why such a conceptual turmoil exists at national and international level. Against the background Section IV proposes a taxation concept for internationally portable pensions that is grounded in the consumptiontype treatment of retirement income provisions and that combines frontloaded taxation (i.e. taxing contributions) with back-loaded taxation (i.e. taxing benefits when disbursed) through the deferment of accumulated tax liabilities till benefits are disbursed or the savings are transferred abroad. Finally, Section $\mathbf{V}$ draws key conclusions and proposes next steps.

\section{The scope of an internationally mobile labor force}

For the world as a whole those residing abroad amount in 2014 to over 3 percent of the world population, with the data representing a mixture non-nationals and foreign-born (UN estimate for 2014, UN 2014). Albeit important in absolute terms (some 230 million people) and rising, this number of possible individuals concerned may not create special attention. The same figure for the European Union (EU) is 4 percent if measured as non-nationals from outside the EU residing there and potentially returning to their home. Adding those EUnationals residing in another EU country amounting to 2.7 percent, the total share of nonnationals residing in an EU country accumulates to 6.7 percent (Eurostat estimates for Jan 1, 2013; Eurostat 2015). The variance among EU member countries of this non-national percentage of population is large and ranges from hardly above 1 percent (Lithuania) to 43 percent (Luxembourg). Mostly even higher mobility figures are achieved when instead of non-nationals we explore the data for those born abroad (the difference being essentially those that got nationalized). The share of foreign born (outside the EU) amounted to 6.6 percent of EU population in 2013 while the share of those born in a different EU country residing abroad within the EU amounted 3.4 percent totaling almost 10 percent of EU population (Eurostat 2015). The variance across EU countries of this percentage is also high but overall somewhat lower and result from positive as well as negative differences to the share of nationals residing abroad.

From the two immigration concepts - non-nationals and foreign born - the first is quite likely the more relevant to establish a low estimate. Non-nationals in a country are more likely to move on or return to their home country; else they have an incentive to acquire the nationality of the residence country while working (thus becoming a foreign born resident), while for retired residents naturalization offers some but altogether fewer advantages. But some of the foreign born that got naturalized may have acquired rights from their former 
home country that could be added to a non-national estimate to establish a high lower bound).

Yet, while impressive, these demographic stock variables still underestimate the importance of mobile individuals between countries as an increasing number work at least for some part of their life in at least one other country before moving back home or continuing to another country of work or retirement. The possibility of multiple spells in different or the same country and the absence of relevant data do not allow pinpointing the share of individuals in the EU population that have or will have had at least one relevant migration experience over their life cycle. However, we can get some magnitudes from the immigration flow data for the 28 EU countries in 2013 that is disaggregated by the same country (i.e. return migration), another EU country and a non-EU country. The flows of all migrants to EU countries in 2013 amounted to 3.389 million; compared to the EU-wide stock of nonnational migrants of 34.070 million this amounts to almost 10 percent distributed among return migrants to their own country, EU and non-EU nationals as 2.4, 3.5 and 4.0 percentage points. A turnover of 10 percent per year with a migrant share of 6.7 percent in the population can be translated into an estimation of the share of population that had at least one migration experience in life. For this we need to assume the relevant active life span, say 40 years and an average length of stay as migrant, say of 10 years. Then the mobility stock estimate for 2013 of 6.7 percent (migrants by nationality definition in percent of population) would translate into a more relevant flow estimate of 4 (i.e. 40/4) times 6.7, i.e. 26.8 percent (i.e. share of individuals in the population that had one migration experience). As the typical age cohort for migration is more between 15 to 30 years of age than a full 15 to 60 years of age, migration spell is, on average, less than 10 years while, on average, individuals that go abroad have typically more than one spell our rough estimate needs to downward or upward adjusted, as appropriate. Some simple modelling and first estimates that make the results of different data bases consistent suggest that based on 2013 data some 20 [+/- 5] percent of EU population may have lived abroad and thus be potential candidate for the issues of pension portability and taxation, discussed next. And this share has been rising over recent decades and is conjectured to continue rising for the time being.

A backward looking glimpse into the rising importance of pensions paid abroad can be achieved by presenting country examples with data on total pensions, o/w old-age pensions and the share of those paid abroad for available years. We have available data for Austria, Germany and Switzerland for 2004, 2010, and 2014 (see Table 1).

In all countries the number of all pensions and old-age pensions' increases in the period of 2004 to 2013/14 but the pensions paid abroad increases even faster. As a result, the share of pensions paid abroad to all pensions increases by below 1 percentage point in Austria reaching $11.8 \%$ by 2014 , over 1 percentage point in Germany reaching $6.9 \%$ by 2013, and almost 1 percentage in Switzerland reaching 10.2 percent by 2014 . The lower share in Germany can be explained by the essential absence of guest workers and pensioners living abroad in the former East Germany before the unification in 1989. From 1992 to 2013 the 
number of all pensions increased by 30.3 percent, those pay abroad by 101.5 percent, i.e. more than doubling.

Table 1. Total number of pensions and those send abroad, End- December 2004, 2009/10 and 201

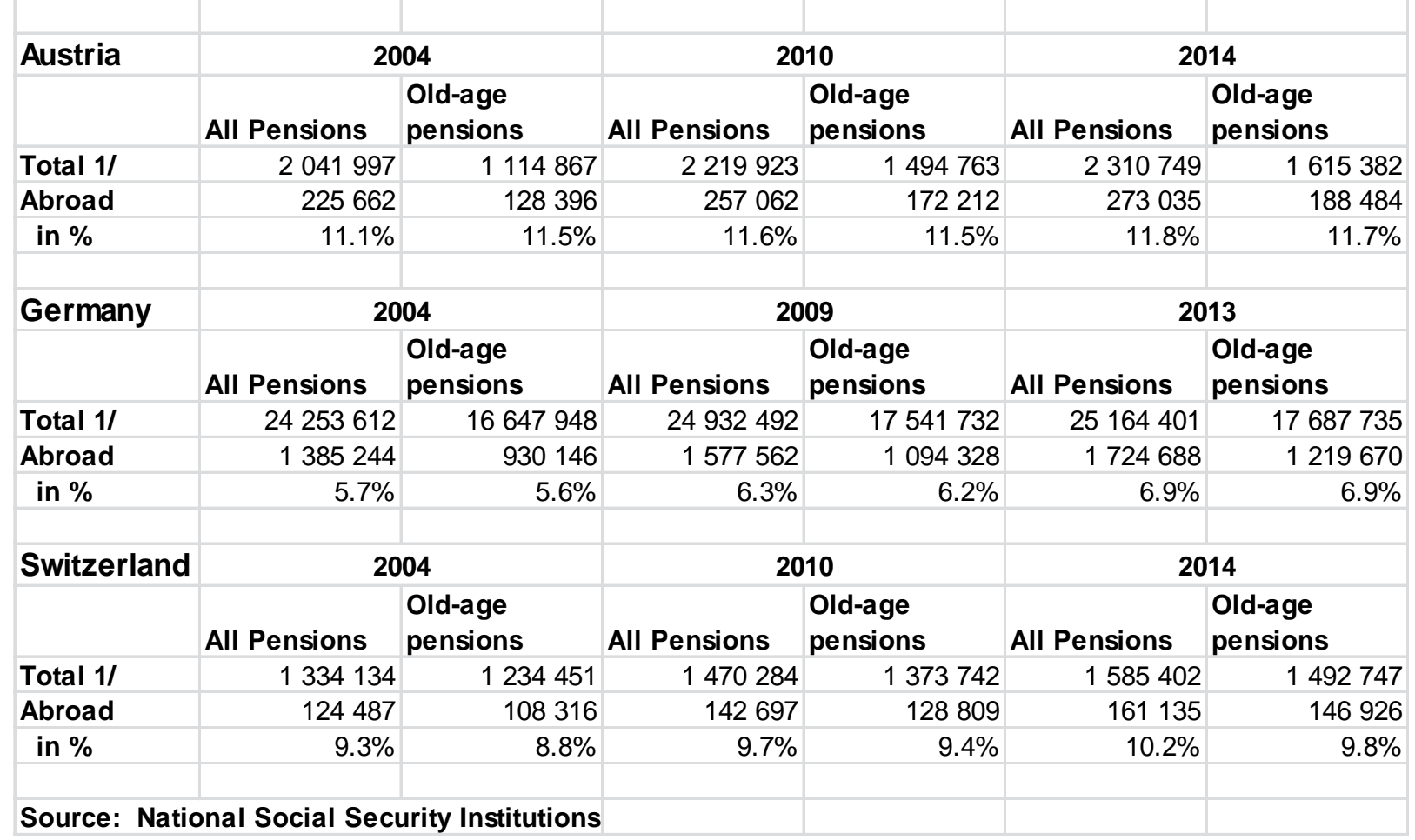

Thanks to German thoroughness in data collection we are able also to get closer insights into distribution of pensions paid abroad by world regions and countries, with latest available data for December 31, 2013; see Table 2. 90 percent of pensions paid by Germany go to Germans residing at home or abroad; 10 percent to non-nationals residing in Germany or abroad. Of those pensions paid to Germans 99 percent are paid within Germany and 1 percent abroad. For non-nationals the figures are 41 percent and 59 percent, respectively signaling that less than half of former non-national workers stay in Germany after retirement. The destination countries of German retirees abroad signal top locations; mostly in the EU (69 percent, with the top 4 countries covering almost 2/3), Other Europe (14\%, with Switzerland making-up 84 percent), and the Americas ( $11 \%$, with the US - Florida? - making-up more than half of the share). 
Table 2. Germany: Number of Pensions to German and Foreign Insured by Types of Pension and Country of Disbursement, December 31, 2013

\begin{tabular}{|c|c|c|c|c|c|c|c|c|c|c|c|c|c|c|c|c|c|}
\hline \multirow{3}{*}{$\begin{array}{l}\text { Disburs } \\
\text { ement } \\
\text { Country }\end{array}$} & \multirow{3}{*}{$\begin{array}{l}\text { Pensions: } \\
\text { German } \\
\text { and }\end{array}$} & \multirow{2}{*}{$\begin{array}{l}\text { Pensions } \\
\text { German }\end{array}$} & \multicolumn{2}{|c|}{ Disability pensions } & \multicolumn{2}{|c|}{ Old-age pensions } & \multicolumn{3}{|c|}{ Sunivors pensins } & \multirow{2}{*}{$\begin{array}{l}\text { Pensions } \\
\text { Foreign }\end{array}$} & \multicolumn{2}{|c|}{ Disability pensions } & \multicolumn{2}{|c|}{ Old-age pensions } & \multicolumn{3}{|c|}{ Survivors pensins } \\
\hline & & & Men & Women & Men & Women & Widows & Widowers & Orphans & & Men & Women & Men & Women & Widows & Widowers & Orphans \\
\hline & & \multicolumn{8}{|c|}{ German insured } & \multicolumn{8}{|c|}{ Foreign insured } \\
\hline Germany & 23439713 & 22380596 & 776598 & 765526 & 6701912 & 9071437 & 4194588 & 565486 & 296647 & 1059117 & 69906 & 73474 & 397529 & 297197 & 166946 & 19800 & 33310 \\
\hline $\begin{array}{l}\text { In } \% \text { of } \\
\text { total/sub- } \\
\text { totals 1/ }\end{array}$ & $93 \%$ & $95 \%$ & $3.47 \%$ & $3.42 \%$ & $29.95 \%$ & $40.53 \%$ & $18.74 \%$ & $2.53 \%$ & $1.33 \%$ & $5 \%$ & $6.60 \%$ & $6.94 \%$ & $37.53 \%$ & $28.06 \%$ & $15.76 \%$ & $1.87 \%$ & $3.15 \%$ \\
\hline $\begin{array}{l}\text { In \% of } \\
\text { total }\end{array}$ & & $99 \%$ & & & & & & & & $41 \%$ & & & & & & & \\
\hline Abroad & 1724688 & 221766 & 3532 & 3374 & 80458 & 77765 & 45989 & 5079 & 5530 & 1502922 & 17875 & 9061 & 672011 & 389436 & 386242 & 19280 & 8983 \\
\hline $\begin{array}{l}\text { In } \% \text { of } \\
\text { total/ sub- } \\
\text { totals } 1 /\end{array}$ & $7 \%$ & $13 \%$ & $1.6 \%$ & $1.5 \%$ & $36.3 \%$ & $35.1 \%$ & $20.7 \%$ & $2.3 \%$ & $2.5 \%$ & $87 \%$ & $1.2 \%$ & $0.6 \%$ & $44.7 \%$ & $25.9 \%$ & $25.7 \%$ & $1.3 \%$ & $0.6 \%$ \\
\hline $\begin{array}{l}\text { In \% of } \\
\text { abroad/ } \\
\text { sub- } \\
\text { totals 1/ }\end{array}$ & & 21 & & & & & & & & 21 & & & & & & & \\
\hline EU & $69 \%$ & $51 \%$ & $2.0 \%$ & $2.0 \%$ & $33.7 \%$ & $34.7 \%$ & $22.1 \%$ & $2.8 \%$ & $2.7 \%$ & $72 \%$ & $1.4 \%$ & $0.7 \%$ & $46.7 \%$ & $24.4 \%$ & $24.9 \%$ & $1.3 \%$ & $0.5 \%$ \\
\hline Austria & & $9 \%$ & $2.7 \%$ & $3.2 \%$ & $30.8 \%$ & $33.5 \%$ & $24.5 \%$ & $2.3 \%$ & $3.0 \%$ & $9 \%$ & $3.9 \%$ & $2.0 \%$ & $41.1 \%$ & $30.7 \%$ & $20.6 \%$ & $0.9 \%$ & $0.9 \%$ \\
\hline France & & $14 \%$ & $1.8 \%$ & $1.8 \%$ & $35.5 \%$ & $35.9 \%$ & $1.5 \%$ & $1.9 \%$ & $1.6 \%$ & $6 \%$ & $3.4 \%$ & $1.8 \%$ & $38.9 \%$ & $37.9 \%$ & $16.1 \%$ & $1.2 \%$ & $0.7 \%$ \\
\hline Italy & & $6 \%$ & $\%$ & $1.1 \%$ & $19.4 \%$ & $52.7 \%$ & $3.7 \%$ & $5.9 \%$ & $1.6 \%$ & $33 \%$ & $0.9 \%$ & $0.2 \%$ & $52.4 \%$ & $17.8 \%$ & 27 & $1.1 \%$ & 3 \\
\hline Spain & & $17 \%$ & $1.8 \%$ & $1.7 \%$ & $35.5 \%$ & $38.2 \%$ & $18.1 \%$ & $3.3 \%$ & $1.4 \%$ & $19 \%$ & $0.8 \%$ & $0.3 \%$ & $51.1 \%$ & $22.4 \%$ & $24.1 \%$ & $1.0 \%$ & $0.2 \%$ \\
\hline $\begin{array}{l}\text { Other } \\
\text { Europe }\end{array}$ & $14 \%$ & $14 \%$ & $1.7 \%$ & $2.0 \%$ & $40.8 \%$ & $35.9 \%$ & $15.4 \%$ & $1.9 \%$ & $2.3 \%$ & $13 \%$ & $1.1 \%$ & $0.6 \%$ & $42.7 \%$ & $18.4 \%$ & $34.7 \%$ & $1.3 \%$ & $1.3 \%$ \\
\hline $\begin{array}{l}\text { Switzerla } \\
\text { nd }\end{array}$ & & $84 \%$ & $1.4 \%$ & $1.8 \%$ & $43.5 \%$ & $37.7 \%$ & $12.5 \%$ & $1.1 \%$ & $1.9 \%$ & $14 \%$ & $0.8 \%$ & $0.9 \%$ & $41.1 \%$ & $47.5 \%$ & $8.1 \%$ & $1.1 \%$ & $0.4 \%$ \\
\hline Africa & $1 \%$ & $4 \%$ & $0.6 \%$ & $0.3 \%$ & $44.4 \%$ & $28.5 \%$ & $21.9 \%$ & $2.1 \%$ & $0.2 \%$ & $0 \%$ & $0.0 \%$ & $0.0 \%$ & $0.0 \%$ & $0.0 \%$ & $0.0 \%$ & $0.0 \%$ & $0.0 \%$ \\
\hline $\begin{array}{l}\text { South } \\
\text { Africa }\end{array}$ & & $71 \%$ & $0.2 \%$ & $0.1 \%$ & $47.4 \%$ & $28.4 \%$ & $21.5 \%$ & $1.6 \%$ & $0.9 \%$ & $14 \%$ & $0.1 \%$ & $0.0 \%$ & $44.2 \%$ & $26.0 \%$ & $28.1 \%$ & $1.3 \%$ & $0.2 \%$ \\
\hline Americas & $11 \%$ & $22 \%$ & $0.4 \%$ & $0.6 \%$ & $34.5 \%$ & $41.5 \%$ & $19.8 \%$ & $1.2 \%$ & $1.7 \%$ & $9 \%$ & $0.1 \%$ & $0.1 \%$ & $36.8 \%$ & $42.4 \%$ & $19.8 \%$ & $0.7 \%$ & $0.1 \%$ \\
\hline USA & & $52 \%$ & $0.3 \%$ & $0.9 \%$ & $30.9 \%$ & $51.0 \%$ & $14.8 \%$ & $1.1 \%$ & $1.1 \%$ & $59 \%$ & $0.1 \%$ & $0.1 \%$ & $32.4 \%$ & $47.2 \%$ & $19.3 \%$ & $0.7 \%$ & $0.1 \%$ \\
\hline Asia & $3 \%$ & $4 \%$ & $0.4 \%$ & $3.0 \%$ & $44.9 \%$ & $12.3 \%$ & $29.8 \%$ & $2.8 \%$ & $6.9 \%$ & $3 \%$ & $0.2 \%$ & $0.1 \%$ & $33.2 \%$ & $39.8 \%$ & $24.1 \%$ & $2.2 \%$ & $0.5 \%$ \\
\hline Israe & & $15 \%$ & & $0.4 \%$ & $.9 \%$ & $26.3 \%$ & $.9 \%$ & $4.3 \%$ & $0.9 \%$ & $93 \%$ & $0.1 \%$ & $0.0 \%$ & $31.9 \%$ & $41.6 \%$ & & $2.3 \%$ & 0.0 \\
\hline Thailand & & $42 \%$ & $4.0 \%$ & $0.2 \%$ & $54.1 \%$ & $4.6 \%$ & $28.5 \%$ & $2.4 \%$ & $6.0 \%$ & $1 \%$ & $3.9 \%$ & $1.5 \%$ & $56.4 \%$ & $20.5 \%$ & $12.7 \%$ & $1.2 \%$ & $3.7 \%$ \\
\hline Australia & $2 \%$ & $5 \%$ & $0.9 \%$ & $0.8 \%$ & $45.0 \%$ & $34.1 \%$ & $16.6 \%$ & $2.0 \%$ & $0.7 \%$ & $2 \%$ & $0.4 \%$ & $0.3 \%$ & $41.7 \%$ & $36.8 \%$ & $18.9 \%$ & $2.0 \%$ & $0.0 \%$ \\
\hline Total & 25164401 & 22602362 & 780130 & 768900 & 6782370 & 9149202 & 4240577 & 570565 & 302177 & 2562039 & 87781 & 82535 & 1069540 & 686633 & 553188 & 39080 & 42293 \\
\hline & & $90 \%$ & $3.5 \%$ & $3.4 \%$ & $30.0 \%$ & $40.5 \%$ & $18.8 \%$ & $2.5 \%$ & $1.3 \%$ & $10 \%$ & $3.4 \%$ & $3.2 \%$ & $41.7 \%$ & $26.8 \%$ & $21.6 \%$ & $1.5 \%$ & $1.7 \%$ \\
\hline
\end{tabular}

Source: Deutsche Rentenversicherung, Rentenbestand am 31.12. 2013, Tabelle 18:00 G

Notes: $1 /$ Integer values in percent and bold refer to the totals, values with percentage points and in Italic refer to pension types to German or foreign pensions, respectively.

$2 /$ Integer values in percent refer to the regional subtotals. 


\section{Portability of Pensions: Issues, Concepts, and Implementation Challenges}

For pension benefits to become taxable abroad they first need to be made portable across international borders. This begs the question why we should worry about pension portability before trying to define portability and the operational objectives behind. The next stage is then to identify the main policy instruments to establish portability and the conceptual considerations behind. With these basic considerations we are equipped to address the taxation of portable pensions. ${ }^{4}$

\section{(i) Why do/should we worry about benefit portability and a lack thereof?}

There are two levels of concern that can be raised for the portability - or the lack thereof - of pension benefits or more broadly of acquired social rights by individuals: Concerns at the level of the individual and concerns at the level of the society (Table 3).

Table 3. Concerns about Portability or the Lack Thereof

\section{Individual Level}

Impedes/distorts individual labor mobility

Impacts life-cycle social risk management

Impinges on acquired social rights

\section{Society Level}

Affects resource allocation and growth

Affects fiscal fairness between sending and receiving country

Impinges on human rights

\section{Source: Author}

If individuals know or expect that pensions (and other social benefits) cannot be ported to their next country of work or to their future retirement residency, or not to the full extend, they may have second thoughts about going abroad in the first instance. If the salary abroad is sufficiently high and/or the proposed work sufficiently interesting, they may still migrate, migrate for a shorter time span, or migrate indefinitely and not return home. Whatever the decision is, lacking or incomplete benefit portability risks impeding or distorting labor mobility at individual level with negative implications for individual welfare through lower human capital development, life-time wealth and life chances.

The reduced/distorted individual mobility translates at society/macroeconomic level quite likely into distorted resource allocation and in lower economic growth. While the exact mechanism of how lower/distorted labor mobility translates into negative macroeconomic economic effects is astonishingly little explored, there is country specific evidence (say, GCC countries) and international conjectures (say, the middle income trap) that impeded national labor mobility negatively effects growth prospects. At international level distorted labor mobility risk affecting resource allocation and growth through lower skill acquisition for nationals (as return migrants), less competitiveness for global talents (as immigrants), and reduced international arbitrage opportunities (including during macroeconomic adjustments).

If individuals are internationally mobile despite incomplete benefit portability this will affect the social risk management over the life cycle for themselves and their families. Outside pensions, it may mean temporary or even permanent loss of health insurance coverage. Within pensions it may mean lower disability or survivor's benefits while working and lower old age

\footnotetext{
${ }^{4}$ For further and fuller discussions on portability issues, see Holzmann et al. 2005, Holzmann and Koettle 2015, and Holzmann 2015.
} 
benefits for a given retirement age or later retirement to recover the portability losses. But whatever the consequences and reactions, lower portability risks impacting negatively the risk management across the life cycle.

At society/fiscal level, incomplete portability between countries affects the fiscal fairness between sending and receiving country. If acquired rights are not made portable the fiscal situation of the sending country has improved as the net pension obligations got reduced at the detriment of the mobile individual. For the receiving country the incomplete portability may, at best, be fiscally irrelevant if future benefits are tightly linked with future contributions. However, in case of benefits geared toward the lower income/lower contribution periods the receiving country would be negatively affected.

Last but not least, incomplete portability impinges on acquired social rights of the individual that receive much attention in social and economic development in recent years. The macroeconomic equivalent is the notion of human rights that are violated if portability of acquired rights is incomplete.

\section{(ii) Defining Portability and Operationalizing the Objectives}

After having briefly presented key concerns about incomplete portability and before discussing the main policy instruments to address them it is time to offer a definition of portability and to operationalize the objectives.

The proposed portability definition is as follows (Holzmann and Koettle 2015):

Portability of social benefits is the ability to preserve, maintain and transfer vested social security and private rights or rights in the process of being vested, independent of profession, nationality and country of residency, with 2 elements:

The full receipt of vested and eligible social security rights as well as rights under private sector arrangements (benefits in disbursement, health care coverage) based on acquired rights through prior contributions/premiums or residency criteria in any chosen residency

The full transfer of social security rights as well as rights under private sector arrangements that are in the process of being vested before eligibility has been established based on acquired rights through prior contributions/premiums or residency criteria in any chosen residency

The first of these two elements is the one that comes to one's mind when talking about benefit portability, namely to receive benefits for which eligibility has been established wherever you live in the world. The background for the eligibility being (beside age) prior contributions, fulfilling of vesting or residency criteria as for those remaining in the country; i.e. eligible benefits are fully exportable. The contribution or residency requirement means that not all benefits can be exported; in particular non-contributory benefits paid from general revenues will be typically subject an exportability ban (such as pension top-ups to achieve guaranteed minimum income in old age).

The second of these elements refers the transfer of rights in the process of being vested before eligibility has been established. Transferring these rights in full can happen (almost) physically when the accumulated resources of a define contribution plan are passed-on to the new country of residency. It can also happen virtually if the rights are preserved in the country of accumulation till eligibility has been achieved. 
A crucial aspect of pension portability is linked to the existence of vesting periods (i.e. minimum insurance periods/years as an eligibility criterion) that in many countries are still in the range of 10,15 or more years. Thus a mobile insured may have acquired insurance-based rights in different countries that fall all short of the vesting period. Without coordination mechanism portability would not exist.

The proposed operational objectives of benefit portability that serve as selection criteria for policy instruments is as follows (Holzmann et al. 2005, Holzmann and Koettle 2015).

A variety of objectives can be raised to support the demand for full portability of social benefits. But ultimately, they boil down to two: fairness and efficiency.

Fairness considerations can be raised at the individual and country levels. If an individual has contributed (mandatorily or voluntarily) to programs to mitigate future risks to allow him or her to smooth consumption across states of the world, then acquired rights should be portable across time and space as a matter of fairness. Similar considerations apply at the country level. If an individual moves between countries, denying him portability of acquired rights provides a windfall profit for the home country. Its mobile work force leaves without accumulations due while potentially burdening the new country of residency.

Efficiency considerations of portability are closely linked with the labor market, but go beyond. Full portability should render the labor mobility, labor supply, and residency decision independent of social benefits. In the absence of full portability, individuals (and families) may decide not to migrate or return, or may decide to offer labor in the informal sector, possibly with stark implications for the overall tax revenues and economic growth of their home country.

To assess whether portability arrangements succeed in delivering on fairness and efficiency considerations, three broad results criteria have been suggested (Holzmann, Koettl and Chernetsky 2005; Holzmann and Koettle 2015):

Criteria 1: No benefit disadvantage with regard to pension and health care for migrants and their dependents. Movements between host countries or back to the home country should not lead to lower pension benefits or gaps in health coverage than if one stayed in one country.

Criteria 2: Fiscal fairness for host and home countries. No financial burden should arise for the social security institution of one country while the social security institutions of the other country benefit from any provisions on portability or the lack thereof.

Criteria 3: Bureaucratic effectiveness. The administrative provisions on portability or the lack thereof should not cause an undue bureaucratic burden for the institutions involved and should be easy to handle for migrants.

\section{(iii) Approaches to establish portability}

There are essentially three approaches to establish portability: First, and most traditional is to develop, sign and implement a bi-lateral social security agreement between 2 corridor countries. Second, not new but in upswing is to allow for international providers of the benefit service across countries. Third and more radical is to redesign of contribution/benefit programs to make them more/fully neutral to mobility.

\section{Bilateral Social Security Agreements (BSSAs)}

BSSAs are the centerpiece of current portability arrangements between countries. They strived to establish the portability of social benefits between two countries and thereby serve 
multiple goals, including: defining which social benefits will be coordinated ("material scope"); defining the individuals covered under the agreement ("personal scope"); establishing the depth of coordination (from time-limited exemptions to contribute to the host scheme to exportability of benefits to full-fledged coordination); and establishing coordination on eligibility criteria, benefit calculation, disbursement, service delivery, financing, and processes of application, decision, and information.

Most of the bi-lateral agreements have been established between developed economies, with a limited number of agreements only between key migration corridor countries. While all EU countries have nowadays bilateral agreements between them, the rules between EU member countries are constraint by the corresponding EU directives. These diverse directives, however, cover not only social security benefits (i.e. first pillars pensions) but also occupational pensions and personal pensions with more or less precision and (individual, country and industry) support.

While wide spread and overall positively assessed, bilateral agreements have so far never been subject to any evaluation with regard to any proposed objectives. The first BSSA evaluation ever between four corridors of EU and neighboring countries (Austria-Turkey, Germany-Turkey, Belgium-Morocco and France-Morocco) has recently been finished and is summarized in Holzmann (2015). In a nutshell, the four BSSA work overall reasonably well; most pension benefit concerns are at the level administration and information not benefit coordination.

\section{Facilitating Multinational Providers}

A promising approach is to use the services of multinational (private sector) providers, at least for supplementary benefits in health care and old age. Multinational providers exist and function well for health care benefits; e.g., Van Breda (recently renamed Cigna), a Belgium service provider, services World Bank staff and retirees residing in Europe, and is also used by the European University Institute. Multinational provider arrangements have been discussed, and sometimes implemented, for supplementary pensions of international workers in multinational enterprises.

In October 2014 the EU Commission announced a "new pan-European pension fund" RESAVER: Retirement Savings Vehicle for European Research Institutions. In order to boost mobility of researchers in Europe the European Commission launched a consortium that aims to establish a new pan-European pension arrangement. Once put in place, the RESAVER initiative would mean that researchers could move freely without having to worry about preserving their supplementary pension benefits. It will enable researchers to remain affiliated with the same pension fund, even when changing jobs and moving between different countries. The European Commission will cover the initial set up costs through a four-year framework contract. In 2015 the employer consortium should prepare the ground for the effective establishment of RESAVER with the aim of transferring the first contributions as of 2016. ${ }^{5}$ The tax treatment is still being worked out ...

\section{Redesigning the contribution/benefit structure}

This approach attempts to address the underlying conceptual issues of lacking portability. It suggests that portability can be easily established with a benefit design that distinguishes between the three components of essentially any social benefit: The period insurance

\footnotetext{
${ }^{5}$ For details of this evolving program see the web-site http://ec.europa.eu/euraxess/index.cfm/rights/resaver
} 
component; the intertemporal savings component; and the redistributive component (Holzmann and Koettle 2015).

$>$ The period insurance component is consumed in any period and thus is not portable and there is no need for it. For (modern) pension schemes, it is the period coverage under a disability or survivors' benefit program that is linked to an old-age pension scheme.

$>$ The intertemporal savings component exists in essentially all social benefits program to a larger and smaller extend as period markets do not exist for diverse reasons and presaving is advised to take account of rising risk or prices and imperfect markets. For oldage pensions it is the accumulated financial or virtual capital at any moment. And such savings accumulation of almost equal importance exists also for health care programs (funded or unfunded). This saving should be fully portably.

$>$ Social programs include also to a larger or smaller extend a (positive or negative) redistributive component that accumulates over time. Whether such a component becomes portable is a political decision that needs to be settled between countries. If it small or non-existent benefit portability is technically and politically much easier.

As regards pensions, the portability is very much facilitated when moving from a defined benefit to defined contribution scheme in which disability and survivor's pensions are separately organized and priced. For old-age pensions the accumulated saving can be easily transferred (whether actual or notional) during the accumulation phase; they do not require any relevant vesting period as under a DB scheme; and the annuitization can take place in the last place of work for the total accumulation.

Text Box 1 sketches the analytical model that outlines the portability conditions when the three components are separated. It will be used in an extended version in Section IV when income taxes are introduced.

Basically the model suggest that as long as benefit program is actuarially fair as the accumulated (actual or virtual) savings reflect the balance of accumulated period contributions and expected period benefits, the transfer of this amount at the time of migration should treat the individual fair and also the sending and receiving country. In the receiving country the transferred amount should be equal the expected contribution - benefit difference (assuming homogenous conditions on both sides of the border). If a redistributive individual component exists (that can be positive or negative) arrangements across all migration flows need to be established and, if needed and agreed, side payments made.

\section{The Taxation of Internationally Portable Pensions: Key Dimensions of Complexity}

While the issues of portability of pensions (and other social benefits) received some albeit still limited attention by economists over the recent decade, the issue of the taxing of portable pensions remains for the time being largely an unexplored area by economists while keeping tax lawyers busy. More broadly, how to best tax pensions even at national level in general and how to do so in the face of population aging and globalization has not yet attracted very much attention by the economic profession. The taxation of internationally portable pensions is terra incognita for the economic profession. 


\section{Box 1: The insurance, saving and distributive components of social insurance benefits: A simple analytical model on full portability (excerpt)}

The insurance component of a one-period benefit with homogenous individuals, without presaving and redistribution, has a simple budget constraint:

[B.1] $\quad \mathrm{c}(\mathrm{a})=\mathrm{b}(\mathrm{a}) \mathrm{p}(\mathrm{a})=\mathrm{E}[\mathrm{b}(\mathrm{a})]$

with c(a) the contribution/insurance premium at age a, b(a) the benefit paid in case of risk realization, $p(a)$ the probability of the risk, and $E[b(a)]$ the expected benefit. The insurance is actuarially fair and the aggregation over (homogenous) individuals assures budget balance.

If pre-saving is introduced to address rising risk or price, the period budget constraint is extended to:

[B.2] $\quad \mathrm{c}(\mathrm{a})-\mathrm{E}[\mathrm{b}(\mathrm{a})]=\mathrm{s}(\mathrm{a})$

with s(a) the period pre-savings available at the end of period a. If moving between countries, the individual now has accumulated pre-savings that he needs to take along to establish portability.

Accumulating the individual savings till an (arbitrary migration at) age ã and using capital letters for the aggregated amounts at this age (measured at end-period) gives:

$$
S(\tilde{\mathrm{a}})=\sum_{a=1}^{\tilde{\mathrm{a}}} s(a)(1+r)^{\tilde{\mathrm{a}}-a}=\sum_{a=1}^{\tilde{\mathrm{a}}}[c(a)-\mathrm{E}[b(a)]](1+r)^{\tilde{\mathrm{a}}-a}=C(\tilde{\mathrm{a}})-B(\tilde{\mathrm{a}})
$$

with $r$ the rate of return provided by the system and consistent with the macroeconomic budget balance. C(ã) are the aggregated contributions paid into the system plus the returns received; $B(\tilde{a})$ is the aggregated (present) value of the insurance component and is independent of any benefits received.

At the time of migration (the beginning of period ã+1), the present value of the (expected) future benefits $\mathrm{Be}(\tilde{a}+1)$ minus the present value of any (expected) future contributions $\mathrm{Ce}(\tilde{a}+1)$ till the latest possible age of death ad in the new host country is:

$$
B^{e}(\tilde{\mathrm{a}}+1)-C^{\mathrm{e}}(\tilde{\mathrm{a}}+1)=\sum_{a=\tilde{\mathrm{a}}+1}^{\mathrm{a}^{\mathrm{d}}} \frac{b(a) p(a)}{(1+r)^{\mathrm{a}-\tilde{\mathrm{a}}+1}} \sigma(\tilde{\mathrm{a}}+1, a)-\sum_{a=\tilde{\mathrm{a}}+1}^{\mathrm{a}^{\mathrm{d}}} \frac{c(a)}{(1+r)^{\mathrm{a}-\tilde{\mathrm{a}}+1}} \sigma(\tilde{\mathrm{a}}+1, a)
$$

The present value of the future benefits depends on the survival probability from migration age ã to age $\mathrm{a}-\sigma(\tilde{\mathrm{a}}+1, \mathrm{a})$, the benefit level $\mathrm{b}(\mathrm{a})$, and the probability (risk) of using the benefit $\mathrm{p}(\mathrm{a})$. The latter is typically 1 for pension benefits, but below 1 and rising with age for health care benefits.

If the (new) host country has characteristics similar to the (old) host country, the expected present value of benefits minus contributions is positive and needs to be financed with external financing. If the characteristics of both countries are identical, the accumulated and portable savings provide this financing match:

$$
C(\tilde{\mathrm{a}})-\mathrm{B}(\tilde{\mathrm{a}})=B^{e}(\tilde{\mathrm{a}}+1)-\mathrm{C}^{\mathrm{e}}(\tilde{\mathrm{a}}+1)
$$

Equation [2.5] presents an actuarially fair scheme in which the expected value of future benefits minus future contributions equals the level of savings at each age. If this is not the case, redistribution is taking place in the form of taxation or transfer. Introducing $R(\tilde{a})$ as the present value of the redistribution component at age ã in equation [2.6] completes the exercise; $R(\tilde{a})$ can be positive (a transfer) or negative (a tax).

$$
S(\tilde{a})+R(\tilde{a})=C(\tilde{a})-\mathrm{B}(\tilde{\mathrm{a}})+R(\tilde{\mathrm{a}})=B^{e}(\tilde{\mathrm{a}}+1)-\mathrm{C}^{\mathrm{e}}(\tilde{\mathrm{a}}+1)
$$

Source: Holzmann and Koettl 2015. 
Against this background this section will sketch a limited number of dimensions considered key to facilitate the understanding of the proposal presented in the next Section. This Section starts out by highlighting the complexity and inconsistency of the taxation at national and bi-lateral level that can be summarized as "everything goes". This is followed by a subsection that explores the origin of tax issues for earnings-related portable pensions.

\section{(i) The fiscal treatment of pension pillars within and between countries: Anything goes}

To present the complexity of the taxation of pensions at national and bi-lateral level it is useful to do so by differentiating different pension pillars as the tax treatment is typically quite different. To this end we use the World Bank 5 pillar structure as is it better able to finesses the complexity of pension schemes' objectives and structures across the world (see Holzmann and Hinz, 2005).

Table 4 describes each pillar, offers summaries of the tax treatment by the domestic tax laws and under double taxation treaties, and makes some pertinent comments. The 5 pillar structure builds on the well-known three pillar structure of public, occupation and personal pensions but separates a poverty-oriented zero pillar from the consumption-smoothing first pillar and adds a forth pillar as memorandum item of public and private arrangements for old age, as their very existence or absence have a bearing in scope and depth of the other pillars (such as health care, long term care and housing, or family cohabitation arrangements and community services). As second pillar we define mandated or quasi-mandated funded provisions as they emerged with the Chilean systemic reform revolution. And the third pillar covers occupation and personal pensions that attract government attentions through specific regulation and tax treatment.

To facilitate the presentation, we use abbreviations for (i) benefit types (defined contribution and defined benefits - DC and DB) and their funding (financial/funded or non-financial/ unfunded $\mathrm{F}$ and $\mathrm{N}$ ), and their combination (NDC, FDC, NDB, FDB); (ii) tax treatment of contributions, returns and benefits (exempt or taxed), and their combination with regard to the tax treatment of contributions, returns, and benefits disbursed (e.g. TEE or EET), with special tax treatments capture with lower $t$ (with various super indices); and (iii) country references indicated through international car plate signs.

A review of Table 4 fosters the summary conclusion - everything goes:

First, in all 5 pillars the financing and benefits may raise taxation issues that differ from each other. This includes the tax treatment of the basic provisions of the zero pillar and the possible clawing back of demogrants' outlays with the taxation of additional income.

Second, the national tax treatment of each pillar is typically different across countries as is the tax treatment between pillars for individual countries. I.e. there is very limited similarity of pillar taxation across countries and across pillars for a single country

Last but not least the tax treatment between countries may differ importantly across corridors of the same countries. I.e. double taxation treaties may have different approaches for a single country depending of the partner treaty country. ${ }^{6}$

\footnotetext{
${ }^{6}$ The inconsistency of capital taxation in double taxation treaties in the 1960 is noted in the survey article of Auerbach (2009); his article makes not mentioning at all of the taxation of labor income across borders.
} 
Table 4: The Tax Treatment of Portable Pensions by Pillars

\begin{tabular}{|c|c|c|c|}
\hline Pillar Description & Domestic Tax Treatment & $\begin{array}{l}\text { International Tax Treatment as } \\
\text { per Double Taxation Treaty }\end{array}$ & Comments \\
\hline $\begin{array}{l}\text { Zero pillar: Poverty-oriented basic } \\
\text { benefits, including demogrant (NZ), } \\
\text { means-tested basic pension (AUS), top- } \\
\text { ups as minimum pension or income } \\
\text { guarantee (most industrialized countries) }\end{array}$ & $\begin{array}{l}\text { Typically untaxed but often part of the } \\
\text { tax base (with other income) }\end{array}$ & $\begin{array}{l}\text { Universal pensions need bilateral social } \\
\text { security agreements and may become } \\
\text { taxable in residence country } \\
\text { Top-ups are typically not made portable } \\
\text { and hence no tax issues arises }\end{array}$ & $\begin{array}{l}\text { Indirectly taxed in case of benefit } \\
\text { withdrawals through means testing, } \\
\text { phased-in withdraws for other pension } \\
\text { income, and claw-back for additional } \\
\text { income under income tax }\end{array}$ \\
\hline $\begin{array}{l}\text { First pillar: Basic consumption } \\
\text { smoothing mandated, earnings-related } \\
\text { and unfunded schemes (NDB, NDC) }\end{array}$ & $\begin{array}{l}\text { Predominantly but not uniformly taxed } \\
\text { with under EET (17 out of } 30 \text { OECD } \\
\text { countries, with Germany also a } \\
\text { vanishing exception) }\end{array}$ & $\begin{array}{l}\text { Typically residency based, except for } \\
\text { civil servants benefits (source-taxed), } \\
\text { source tax in some countries (recently in } \\
\text { Germany, formerly in Belgium) and non- } \\
\text { taxation in others (Turkey, Portugal) }\end{array}$ & \\
\hline $\begin{array}{l}\text { Second pillar: Basic or supplementary } \\
\text { consumption smoothing mandated, } \\
\text { earnings-related and funded schemes } \\
\text { (FDB, FDC) }\end{array}$ & $\begin{array}{l}\text { Often t/T-E-t/T/E but also TEE or ttE } \\
\text { (Australia) }\end{array}$ & $\begin{array}{l}\text { Typically taxed similar to the funded } \\
\text { pillar (if supplementary), else any tax } \\
\text { treatment may exist }\end{array}$ & \\
\hline $\begin{array}{l}\text { Third pillar: Supplementary } \\
\text { consumption smoothing voluntary, } \\
\text { earnings related and funded schemes } \\
\text { (corporate and personal; mostly FDC) }\end{array}$ & $\begin{array}{l}\text { Often tax favored which may go as far } \\
\text { as E’EE (Malaysia) but includes also } \\
\text { TEE (Roth IRA: Poland, US) }\end{array}$ & $\begin{array}{l}\text { Typically residency based but may also } \\
\text { assign the right to tax to both source and } \\
\text { residency, hardly ever to source country } \\
\text { only }\end{array}$ & $\begin{array}{l}\text { As supplementary retirement saving is } \\
\text { rarely transformed into an annuity the } \\
\text { resource transfer across borders cannot be } \\
\text { distinguished from dissaving so no or only } \\
\text { source taxation on returns may incur }\end{array}$ \\
\hline $\begin{array}{l}\text { Fourth pillar: memo item for public and } \\
\text { private programs such as health care, } \\
\text { aged care, public housing, cohabitation } \\
\text { and other family support, etc }\end{array}$ & $\begin{array}{l}\text { Taxation issues may emerge for some } \\
\text { programs, such as for contributions to } \\
\text { health care and aged care, or the tax } \\
\text { treatment of family support and reverse } \\
\text { mortgages }\end{array}$ & $\begin{array}{l}\text { Most of the programs are typically not } \\
\text { portable but if they are (such as for some } \\
\text { private health care in retirement) tax } \\
\text { treatment issues may emerge but } \\
\text { typically not included in treaty }\end{array}$ & $\begin{array}{l}\text { These pillar programs have a bearing on } \\
\text { the size of the other pillars and their tax } \\
\text { treatment }\end{array}$ \\
\hline
\end{tabular}

Source: Author, drawing on Genser (2015), Genser and Holzmann (2015), Wellisch et al (2008), and Yoo and de Serres (2004). 


\section{(ii) What are possible origins of tax issues for earnings-related portable pensions?}

The prior sub-section suggests that there is hardly any other field in public economics where there is more diversity within and between countries and less conceptual guidance what should be done. This begs the question why this is the case and how this can be explained (see Genser and Holzmann 2015 for a richer set of alternative explanations). This subsection presents one key explanation around the limitations of traditional and more modern income taxation concepts to establish fiscal fairness between countries with mobile labor force. It claims that the diversity of taxation of portable pensions is due to three elements: (a) The incomplete move from comprehensive income tax for retirement saving (unfunded and funded) toward consumption-type tax treatment; (b) The varying scope and composition of tax preferences within and between countries; (c) The nonequivalence of front- and backloaded consumption taxation TEE and EET. It concludes that (d) that the current taxation approaches are unable to offer fiscal fairness across countries.

(a) The incomplete move from comprehensive income tax toward consumption-type tax treatment

The traditional view on income taxation - the Schanz-Haig-Simon SHS broad-based income tax approach - that dominated the view of economists for almost 100 years and well into the 1970s of how to tax income in a comprehensive manner has a number of advantages: First, it is based on a broad definition of income - the value of consumption and the change in wealth within a period. Second, the broad definition would allow having low and uniform rates across diverse income sources thus avoiding discrimination, keeping distortions low, and providing a lid on tax allowances. Last but not least, a board based income tax is relatively simple for tax payers and relatively easy for tax administrations.

As regards the taxation of retirement income the SHS approach has, however, a number of pitfalls that has contributed to its punctuation and gradual partial demise: First, it is based on annual measurement that penalizes individuals with fluctuating income, and more broadly it does not take account of life-cycle considerations in labor supply and consumption decisions; they came on board only in the 1960. Second, the approach taxes pension savings according to TTE, i.e. not only contribution payments and other retirement saving has to take out of taxed income, also the returns on savings are taxed in the period of realization and thus savings is taxed twice. Last but not least, while the issue of realized vs unrealized returns concern both unfunded and funded system, for unfunded (non-financial) schemes the returns are typically never known in NDB schemes - the traditional workhorse of publicly mandated social insurance pension benefits. This has changed recently with the advance of NDC schemes (Holzmann and Palmer 2006, 2011, 2012).

The 1970s brought an important change in the view about the best tax base - income or consumption. While the traditional indirect consumption tax - whether as older multi-stage turn-over or newer valued added tax - is considered regressive, the theoretical and institutional proposals in the 1970s suggest that an expenditure tax approach that considers individuals across the life cycle may not need a taxation of capital income to be progressive and is operationally feasible (Atkinson-Stiglitz 1976, IFS 1978, and US Treasury 1977); arguments for an individual expenditure tax have existed for decades and include main contributions by Kaldor (1955).

Despite the conceptual advantages of an expenditure tax there are no main countries in the world that ever tried to implement an expenditure tax in full in order to replace a traditional 
income tax structure (Auerbach 2010). The scope of transition issues and its financing held back such an introduction but also doubts about some of the conceptual issues, in particular about the prescription in some models of optimal taxation of a zero capital income tax across the income strata. Yet, with regard to retirement income provisions - whether mandated or voluntary, non-financial or financial - a limited and variable consumption-type treatment of contributions, returns, and payouts has taken hold in most countries. And an expendituretype treatment of pension benefits in the form of TEE or EET is typical the benchmark for most pension economists.

(b) The varying scope and composition of tax preferences within and between countries

What explains that scope and composition of tax preferences that vary with the type of participation (mandated or voluntary), the type of funding (non-financial and financial), the benefit type (DC, DB), but also socio-economic characteristics, etc.? We claim that there are essentially three explanations for the diversity of arrangements:

First, the diversity of arrangements reflects a diverse set of efficiency and equity concerns by government that may change over time and differ across countries. For example, the mostly unlimited deductibility of contributions to a mandated first or second pillar scheme is consistent with the governments' mandate of providing income support within the limits of floor and ceiling. For voluntary schemes - occupation and personal - the limits are typically much tighter and changing over time. With tight deductibility ceilings governments want to avoid that tax privileged wealth accumulation is camouflaged as retirement saving. While unfunded provisions have mostly a back-loaded taxation, funded provisions have both frontand back-loaded taxation that may reflect risk considerations that differ by benefit types, but also considerations of liquidity constraints and concerns of incentives for informality. Defined benefit and defined contribution schemes may have different treatment because DC schemes allow an easy taxation of returns while DBs do not. Last but not least, and very importantly, preferential tax treatment is a way to incentivize voluntary provisions to comply with specific regulatory objectives, else they lose the privilege. A very effective example is the participation requirement across the income strata under the occupational pension schemes in the US Tax code (401k).

Second, not only the objectives of government and individuals are reflected in the tax treatment of retirement provisions but also those of the financial industry that is often very powerful and influential. While the argument that tax preferences are needed to increase the demand for voluntary retirement saving is empirically doubtful, the lobbying efforts by the financial industry continuously build on the argument. The reduction of generosity with regard to public pensions in recent years and the invitation to individuals to increase their own financial retirement provisions has supported the lobbying efforts.

Last but not least, the government induced changes of tax preferences over time reflect also changes in fiscal pressure. In times of tighter budget are tax preferences for voluntary retirement saving an obvious candidate as they were established in better fiscal times. As retirement savings contracts are running over years, if not decades, and tax changes may affect only new contracts, there is a need for transitional arrangements that contribute to the complexity.

\section{(c) The nonequivalence of front- and back-loaded consumption taxation TEE and EET}

A lot of the complexity in pension taxation is introduced by variations in front-loading and back-loading of taxation across schemes, and sometimes some middle ground. Under the 
assumptions of perfect capital markets, strictly proportionate tax rates, etc TEE and EET can be shown to be equivalent. If heterogeneity in rates of return is introduced than the fiscal equivalence requires that the above normal rate of return needs to be taxed (i.e. TtE) as such taxation takes place in the back-loaded case. We ignore this in the following. ${ }^{7}$

The view of broad equivalence of front and back-loaded taxation is shared by many pension economists (including Whitehouse 1999, Robalino et al. 2005, Huang 2008) but not all (see Romaniuk 2013 for review). Actually, there are many more arguments that can be aligned for a difference than equivalence, the most important being:

$>$ Strict equivalence requires not only a constant (marginal) tax rate but also reimbursable (individual) tax credits across the life cycle; many elderly make incomplete use of a tax allowance or tax credit during decumulation. In actual progressive tax schemes with rising marginal tax rates, allowances and credits the effective marginal and average rates differ strongly between work and retirement and thus confer major tax savings to a back-loaded approach.

$>$ The differences in revenue collection/effective tax rates for most countries may be of the order of 3 to 1 and higher for a given tax system. Even taking account of lower tax rates for comparable revenue targets, higher accumulated rates of mandated contributions and income tax rates during working life under TEE is bound to affect labor force participation and informality, at least in emerging countries.

$>$ TEE and EET may differ with regard to risk taking behavior of (funded) DC and DB schemes. Romaniuk (2013) proves that the TEE regime is risk-taking neutral while the EET regime can affect risk taking, however only in the case of DC funds. This theoretical result may explain some of the inconsistencies in empirical research findings and may also offer a rational for the taxation trend observed in US pension saving markets toward TEE.

$>$ The EET tax treatment of (voluntary) retirement saving under an income tax system confers tax privileges that can be linked with regulatory requirements that need to be adhered to. This offers opportunities to bring stronger regulation and supervision to the table than otherwise but also adherence to equal treatment and other policy objectives.

$>$ A TEE approach may be considered not time-consistent as the government has incentives of reversing in the future through additional taxation making this taxation approach not credible and thus potentially unsustainable.

\section{(d) The lack of current taxation approaches offering fiscal fairness across countries}

A consistent application of TEE or EET promises to reduce complexity of taxation within a country. Would it also help to establish fairness across countries? Unfortunately, consistent application of TEE or EET in source and residency country does not guarantee fiscal fairness between countries, even less so under varying applications (i.e. TEE/EET or EET/TEE corridor combination).

\footnotetext{
${ }^{7}$ While the static fiscal equivalence requires the taxation of above-normal rates (or the provision of a normal rate allowance in the annual tax declaration), in a dynamic setting it is not clear that this is justified. As a higher rate of return is linked with higher risk it is the risk-adjusted rate that should matter for portfolio consideration and taxation.
} 
Table 5 offers the individual and countries' perspectives of the application of taxation standards in source country (where the benefit eligibility was created and the benefit paid from) and residence country (where the pension benefit is enjoyed)

Table 5: Expenditure tax standards and taxation outcomes

\begin{tabular}{|l|l|l|}
\hline \multicolumn{1}{|r|}{$\begin{array}{r}\text { Work/ } \\
\text { Residency country }\end{array}$} & TEE & EET \\
\hline TEE & $\begin{array}{l}\text { I: Taxed once in work country } \\
\text { C:Tax revenue in work country }\end{array}$ & $\begin{array}{l}\text { I: Untaxed in both countries } \\
\text { C: No tax revenue in any country }\end{array}$ \\
\hline EET & $\begin{array}{l}\text { I: Double taxation } \\
\text { C:Tax revenues in both } \\
\text { countries }\end{array}$ & $\begin{array}{l}\text { I: Taxed in residence country } \\
\text { C: Tax revenues in residence country }\end{array}$ \\
\hline
\end{tabular}

Source: Author

From an individual perspective the application of the same standard in both source and residency country offers neutrality with regard to mobility decisions and individual fiscal fairness as being taxed only once. The scenario of working in a back-loading country (and paying no taxes for retirement income provisions) while retiring in a front-loading country (and paying no taxes on benefits either) would bias mobility decisions as would be the scenario of being taxed on both countries. This has already raised fears mobile retirees threaten back-loaded taxation (Meier and Wagener, 2015).

From the countries fiscal perspective only the double taxation perspective is a-priori acceptable for both countries. A one-sided taxation has its attraction only if one is on the receiving side or with balanced migration flows. A no-taxation in both countries is a clearly a no-go.

It follows that the common adoption of an expenditure tax standard - either TEE or EET -in both work and residency county is required to establish neutral labor mobility incentives but not sufficient to establish fiscal fairness between countries. The latter will happen only with balanced migration and related fiscal flows. While industrialized countries are nowadays simultaneously immigrant and emigrant countries, the net migration flows are over long periods not zero (Eurostat 2014, UN 2015)

Even if net-migration flows were to be balanced over time, the fiscal flows may not be balanced in case of differences in tax revenue and public expenditure profiles. In this case labor mobility through immigration or emigration makes at least one country worse off. There are nowadays strong and empirically consistent indications of fiscal surpluses created during active life and fiscal deficits that emerge and rise with seniority. This consistent data is emerging from the national transfer accounts (NTA) that cover an increasing number of countries around the world. The data indicates a negative transfer starting around retirement age due to pension receipt and health expenditure increasing exponentially with age but going well beyond these two programs. ${ }^{8}$ Thus an effective fiscal fairness between countries cannot be established by focusing only on the tax revenue stream; the concept needs empirical information on age profiles of both public revenue and expenditure of work and residency country.

\footnotetext{
${ }^{8}$ For countries of the NTA see http://www.ntaccounts.org/web/nta/show; for recent information, concepts and data, see e.g. Lee and Mason 2014.
} 
The tax theory across borders is concerned with efficiency but not with fiscal fairness across countries. As within countries, the idea is to have a tax system that establishes efficiency and maximizes output that in a second step is redistributed across individuals and countries. While such redistribution may partially take place within countries, it does not take place across countries, not even in the EU. And while we have some dated prescription about the taxation of capital income (export vs income neutrality), we have none of this kind for the international taxation of pensions and little conceptualization on fiscal fairness.

\section{A Taxation Concept for Internationally Portable Pensions}

In view of the many drivers of complexity of the current taxation of internationally portable pensions and the many policy demands that this taxation should accomplish, is there any hope for a taxation concept that complies with the key objectives while delivering in an administratively acceptable manner and within the boundaries of double-taxation treaties (DTTs)? What are the operationally possible options, what are the conceptual alternatives? This Section focuses only on a specific proposal that promises to deliver on most but quite likely not all dimensions of the many desiderata. ${ }^{9}$ The proposal mixes notional front-loaded taxation (as the tax due on contributions/savings is deferred) with actual back-loaded taxation as the taxes are due when the benefits are disbursed (in source or residency country) or when accumulated savings effectively leave the country.

To present the proposal, this section proceeds as follows. It starts out with (i) a brief review of objectives and the selection criteria the proposal should fulfil before (ii) the concept is presented; basically it amounts to an expansion of the portability model of Section II by a deferred tax component. Next (iii) the implementation of the concept is sketched and integration with alternative existing country taxation models highlighted. To offer (iv) some magnitudes on the amount of deferment and implication for annuity levels the results of an Australian tax model are presented. The section ends with the discussion with ( $v$ ) a summary of key benefits and outlining a few key conceptual complications.

\section{(i) Objectives and selection criteria}

There are three main objectives that served as selection criteria for the identified and proposed taxation concept.

First, the concept should allow the best possible compliance with the portability objectives outlined in Section 2:

$>$ Labor mobility neutrality, i.e. the taxation concept should not influence mobility decisions in any direction. Everything else equal, if two countries apply the same taxation approach and rates, individuals should be indifferent.

$>$ Fiscal fairness between countries, i.e. countries should fiscally not profit nor be harmed by the mobility of the individual.

$>$ Bureaucratic effectiveness, i.e. the concept should be implemented with low administrative burden for individuals and administration.

Second, and linked with bureaucratic effectiveness but different is the objective that the concept should have a minimum demand on the revision of double taxation treaties. Such revisions are difficult to initiate and even more so to successfully finalize.

\footnotetext{
${ }^{9}$ For a review of further taxation options, see Genser and Holzmann (2015).
} 
Last but not least, the proposal should allow for country flexibility in the use of front- or backloaded taxation (i.e. TEE or EET). While the common use of the concept across countries would be desirable it should also work reasonably well if the partner country of a DTT sticks to the inherited approach.

\section{(ii) A notional front-loaded and actual back-loaded approach to tax portable pensions}

The proposed concept consists of three main components: ${ }^{10}$

(1) A notional front-loading of taxation of retirement income provisions by applying taxation rules as if contributions or saving are paid out of net earnings/income while the actual tax payment is deferred and together with interest accumulated in an own account. Thus, formally and legally the approach corresponds to a front-loaded TEE concept. The deferred tax becomes payable in essentially two cases:

Darliest when the individual moves to a new country and the savings are not kept in the source country/cannot be moved under an equivalent account mechanism to the new residency country

$>$ Latest when the individual retires and receives benefit payment (in source country or residency country), typically as annuity but can also be lump-sum payments

(2) A material back-loading of the taxation as the tax payment is due only when the accumulations are disbursed. As result the economic effects of the concept are germane to an EET scheme, with the following key implications:

$>$ The consumption-tax type incentives for participation in the schemes are retained

$>$ While the deferred taxes are accumulated in an own account and part of gross saving, they are not disposable income. Possible negative liquidity effects due to borrowing constraints may affect the participations in the scheme

(3) A tax payment mode that establishes (potentially) fiscal equality between front- and back loader approach

$>$ For both domestic and foreign recipients of a benefit (annuity), the benefit tax due is calculated as the annuity value of the accumulated deferred taxes plus interests

$>$ If paid abroad the residency state can decide to what extend the tax annuity paid is considered for residency taxation

$>$ The tax annuity can be compared with the hypothetical tax due on the gross annuity disbursed. Under a constant tax rate, equal applied annuity factors, etc the tax amounts should match.

The proposed approach can be considered as an extension of the portability model introduced in Section 2 (Box 2) in which taxes have been added. Thus, under some conditions, the individual and fiscal fairness for portability should be guaranteed. Box 2 provides the model extension and balancing condition.

\footnotetext{
${ }^{10}$ The concept is in line with a proposal by Wellish et al (2008) that comes from the legal corner and confirms its consistency with EU regulation and many DTT.
} 


\section{Box 2: Extending the portability model with taxation}

Actuarial balancing condition (see Section I), without benefits prior exit and no redistributive components, and tax

$$
\text { [1] } C(\tilde{\mathrm{a}})=S(\tilde{\mathrm{a}})=B^{e}(\tilde{\mathrm{a}}+1)=\mathrm{B}^{\mathrm{e}}(R ; \tilde{\mathrm{a}}+1)
$$

Actuarial balancing condition with income tax, differentiation between gross and net benefits, and tax expenditure $\mathrm{E}$ (i.e. deferred tax) through tax-exempt contributions and returns,

$$
\operatorname{Sg}(\tilde{\mathrm{a}})-\mathrm{E}(\tilde{\mathrm{a}})=\operatorname{Sn}(\tilde{\mathrm{a}})=\mathrm{Bn}^{\circledR}(R ; \tilde{\mathrm{a}}+1)=\mathrm{Bg}^{\circledR}(R ; \tilde{\mathrm{a}}+1)-\mathrm{T}^{2}(R ; \tilde{\mathrm{a}}+1)
$$

With the fiscal condition that deferred tax at retirement need to equal expected income tax on gross retirement benefits (as lump-sum, phased withdrawal, or annuity)

$$
\mathrm{E}(\tilde{\mathrm{a}})=\mathrm{T}^{\mathrm{e}}(B g ; R ; \tilde{\mathrm{a}}+1)
$$

Source: Author

\section{(iii) Implementation and consistency with country regulations}

The implementation of the concept is straightforward and a presentation should put some examples on the try bones of the prior sub-section.

(1) Participants in any contributory retirement income scheme have an individual account in which the taxes due and the interests are recorded and accumulated. Thus it works for both DC and DB schemes, financial or non-financial schemes. However, the full logic is more visible when a DC concept is applied. Then we can easily distinguish between net and gross savings accumulations.

Table 6 offers the calculations for an individual that starts out earning 12,000 Euros a year and contributes 20 percent to the scheme while the (average) tax rate is 15 percent. We assume a wage growth of 3 percent and an equal level of interest rate (but both assumptions have no impact on the following conclusions). In the deferred tax model, the accumulated savings (net of deferred tax) amount after 45 years to 396,517 Euros, that of the deferred tax to 59,478 Euros adding-up to a gross saving of 455,994 Euros. The corresponding annuities are 15,861,

\begin{tabular}{|c|c|c|c|c|c|c|c|c|c|}
\hline Year & Gross Earnings & $\begin{array}{r}\text { Annual } \\
\text { contribution }\end{array}$ & $\begin{array}{r}\text { Accumulated } \\
\text { (net) savings }\end{array}$ & $\begin{array}{r}\text { Interest } \\
\text { received }\end{array}$ & $\begin{array}{l}\text { Annual tax } \\
\text { (gross) due }\end{array}$ & $\begin{array}{r}\text { Annual } \\
\text { deferred tax }\end{array}$ & Deferred tax & $\begin{array}{r}\text { Interest on } \\
\text { deferred tax }\end{array}$ & $\begin{array}{l}\text { Accumulated } \\
\text { gross savings }\end{array}$ \\
\hline 1 & 12000 & 2400 & 2400 & 0 & 1800 & 360 & 360 & 0 & 2760 \\
\hline 2 & 12360 & 2472 & 4944 & 72 & 1854 & 371 & 742 & 11 & 5686 \\
\hline 3 & 12731 & 2546 & 7638 & 148 & 1910 & 382 & 1146 & 22 & 8784 \\
\hline 44 & 42774 & 8555 & 376413 & 10714 & 6416 & 1283 & 56462 & 1607 & 432875 \\
\hline 45 & 44057 & 8811 & 396517 & 11292 & 6609 & 1322 & 59478 & 1694 & 455994 \\
\hline $\begin{array}{l}\text { Annuity } \\
\text { (LE } 25 \text { y) }\end{array}$ & & & 15861 & & & & 2379 & & 18240 \\
\hline
\end{tabular}
2,370 and 18,240 Euros, respectively (assuming a life expectancy of 25 years and keeping the assumption of interest rate equals earnings growth with benefits indexed to earnings).

Tabe 6: Deferred taxes and accumulated amounts (in Euros)

Source: Author 
The values of annuities and earnings in the last period allow us to calculate the gross and net replacement rates for the individual for both the deferred tax approach and an EET taxation approach; both are similar but not equivalent (Table 7).

\section{Table 7: Replacement rates under deferred and EET taxation}

\begin{tabular}{|r|r|r|}
\hline Gross RR & $\begin{array}{c}\text { Deferred } \\
\text { taxation }\end{array}$ & $\begin{array}{r}\text { EET } \\
\text { taxation }\end{array}$ \\
\hline Net RR net of tax & 42.4 1/ & $36.02 /$ \\
\hline $\begin{array}{r}\text { Net RR net of } \\
\text { tax\& }\end{array}$ & & $34.84 /$ \\
\hline $\begin{array}{r}\text { contributions } \\
\text { Nent }\end{array}$ & $55.45 /$ & $45.06 /$ \\
\hline
\end{tabular}

Source: Author

Notes: $1 /$ Annuitized gross accumulation to gross earnings in last period

2/ Annuitized net accumulations to gross earnings in last period

3/ Annuitized net accumulations to gross earnings minus total tax in last period

4/ Annuitized net accumulations minus tax on annuity to gross earnings minus total tax in last period

5/ Annuitized net accumulations to gross earnings minus total tax and contribution in last period

6/ Annuitized net accumulations minus tax on annuity to gross earnings minus total tax in last period

The differences emerge as in the case of deferred taxation the savings is taxed with full rate and then deferred, i.e. annual savings times the tax rate, whereas in the EET case savings remain untaxed as the tax is levied only on the earnings net of savings. It results into a nominally higher replacement rate for the deferred taxation as already all taxes are accounted for whereas under the EET taxation the taxes are still due. If under the latter case the individual saves the lower tax burden during activity/higher net earnings and annuitizes the accumulated saving at retirement the same total net annuity emerges.

(2) When individuals migrate to another country before retirement but the accumulations remain in the country the tax deferment is retained and hence no taxes due. Thus for most public schemes and many private retirement schemes taxation only kicks in when disbursement takes place.

When disbursement of the benefits aboard takes place after retirement, the tax annuity is annually payable as a deferred tax liability to the source country, not as a source tax on benefits. With such a reframing this approach is considered consistent with EU regulations and most DTTs (Wellisch et al. 2008). An alternative approach would be to include the annuity value into the tax base, including other taxable income, and to correct the overall tax due for the deferred tax due. Such an approach makes the approach closer to a source taxation of benefits and thus vulnerable to legal disputes; it creates also issues if the tax due under this approach is higher or lower than the annuity value.

The residency country has to decide to what extend it taxes the net benefits transferred and if so how and to what extent it accounts for the taxes already paid in source country. If the country does not tax pension benefits at all (such as Portugal and Turkey) or taxes also under TEE or deferred taxation rules few issues should emerge (except some potential retiree may now change their mobility decisions). If the country follows the residency principle of income taxation, including pensions, then double taxation will emerge unless softened by unilateral concessions or provisions in the double taxation treaty.

When individuals migrate before retirement, change also the location of the accumulated 
savings and the receiving country offers no institutional set-up that enables to prolong the taxdeferred status, then the deferred taxes will have to be paid; this means that only the net savings accumulations can be transferred. Thus the deferred tax becomes effectively an exit tax on exported retirement savings that were granted tax privileges under a comprehensive income tax approach. In the destination country the transferred savings are already net of tax (including on new accumulations at standard rate of return), and thus should not be taxed when disbursed at retirement. This may technically be feasible but may thereby contradict the taxation rules of the destination country. Thus, to prevent this exit tax to become an obstacle for labor mobility one may need to think of keeping the deferred status also in the new country and finding a way to split the deferred taxes at retirement. In a similar direction go current attempts to create a European Pension Funds that is centrally situated but serves researchers and teaching staff across Europe and thus avoids mobility and coverage issues.

\section{(iv) Magnitudes of deferred taxes and tax expenditure}

This sub-section provides information about the magnitude of deferred taxes and tax expenditure based on an Australian country tax model (as available). The purpose is also to outline some of the methodological considerations when undertaking such estimations while offering a bit more information of the working of deferred taxes and tax expenditure of the proposed approach and in comparison to other approaches.

First, the magnitudes of such estimations depend critically on the benchmark that is applied: Is it a comprehensive income tax TTE, a variant of such approach $T^{*} T^{*} E$, the front-loaded consumption tax approach TEE, or some other benchmark; for this estimations we use the comprehensive income tax. Second, the magnitudes and differences depend also critically on the assumed compound/discount rate applied and possible differences in the application for different variables; for this estimation we use constant rates. Third, there are many other assumptions that are relevant for the outcome, such as the shape of the assumed earnings profile, the differences across the income strata etc. Last but not least, the results depend also critically an the detailed mapping of the legal rules as well as on assumptions in what sequence of tax preferences are used in the presence of thresholds and varying marginal tax rates across the income.

Our results that are summarized in Table 8 are based on a spreadsheet model that maps the Australian tax system in order to estimate the tax-expenditure under the current $T^{*} T^{*} \mathrm{E}$ approach against the benchmark of the comprehensive income tax. ${ }^{11}$ In addition the tax expenditure of the front- and back loaded TEE and EET are presented and comparisons across the income strata are provided. For each taxation approach the estimations are done for three earnings data points: Half of average, average, and double of average income corresponding roughly to $37.500,75.000$ and 150.00 AUS\$. The first three columns present the value of tax expenditure (on contributions, on investment returns, and the total), the next three columns the taxes paid (on contributions, on investment returns, and the total), and the next two columns the accumulated savings (the superannuation - the Australian mandated funded pensions - accumulated at age 67, the gross saving GS as sum of taxes paid and superannuation accumulation). The next three columns present variables as percent of gross saving (total tax, total tax expenditure, and the sum). The last four columns provide information on a hypothetical annuity (annuity value in AUS\$, net replacement rate in percent, average tax rate on annuity in percent, and tax on annuity in AUS\$).

\footnotetext{
${ }^{11}$ For more details on the model assumptions and results, see Chomik and Piggott (2015).
} 
Table 8: Tax expenditure under different taxation approaches

Tax Regime TTE: Benchmark

\begin{tabular}{|c|c|c|c|c|c|c|c|c|c|c|c|c|c|c|c|c|}
\hline Yearly Income & In AUS \$ & $\begin{array}{l}\text { Tax Exp on } \\
\text { Contribtion }\end{array}$ & $\begin{array}{l}\text { Tax Exp on } \\
\text { Returns }\end{array}$ & $\begin{array}{l}\text { Total Tax } \\
\text { Exp }\end{array}$ & $\begin{array}{l}\text { Total cont } \\
\text { tax paid }\end{array}$ & \begin{tabular}{|l|} 
Total inv \\
returns tax \\
paid
\end{tabular} & \begin{tabular}{|l} 
Total Taxes \\
paid
\end{tabular} & $\begin{array}{l}\text { Super } \\
\text { accumuled } \\
\text { at } 67\end{array}$ & \begin{tabular}{|l} 
Gross \\
Saving (GS)
\end{tabular} & \begin{tabular}{|l|} 
Total tax in \\
$\%$ of GS
\end{tabular} & \begin{tabular}{|l|} 
Total tax \\
exp in \% of \\
GS
\end{tabular} & $\begin{array}{l}\text { Total tax } \\
\text { and tax exp } \\
\text { in } \% \text { of GS }\end{array}$ & $\begin{array}{l}\text { Net } \\
\text { Annuity } \\
\text { at } 67\end{array}$ & $\begin{array}{l}\text { Net } \\
\text { replace- } \\
\text { ment rate }\end{array}$ & $\begin{array}{l}\text { Avg tax } \\
\text { rate on } \\
\text { AN }\end{array}$ & $\begin{array}{l}\text { Total tax } \\
\text { on AN }\end{array}$ \\
\hline 0.5 of Average & $\$ 37500$ & $\$ 0$ & $\$ 0$ & $\$ 0$ & $\$ 61643$ & $\$ 88356$ & $\$ 150000$ & $\$ 189077$ & $\$ 339077$ & $44.2 \%$ & $0 \%$ & $44 \%$ & $\$ 7272$ & $19 \%$ & $0.0 \%$ & $\$ 0$ \\
\hline 1.0 of Average & $\$ 75000$ & $\$ 0$ & $\$ 0$ & $\$ 0$ & $\$ 141397$ & $\$ 158521$ & $\$ 299918$ & $\$ 302116$ & $\$ 602034$ & $49.8 \%$ & $0 \%$ & $50 \%$ & \$11620 & $15 \%$ & $0.0 \%$ & $\$ 0$ \\
\hline 2.0 of Average & $\$ 150000$ & $\$ 0$ & $\$ 0$ & $\$ 0$ & $\$ 302341$ & $\$ 297732$ & $\$ 600073$ & $\$ 522578$ & $\$ 1122651$ & $53.5 \%$ & $0 \%$ & $53 \%$ & $\$ 20099$ & $13 \%$ & $0.0 \%$ & $\$ 0$ \\
\hline
\end{tabular}

\section{Current Tax Regime T*T*E}

\begin{tabular}{|c|c|c|c|c|c|c|c|c|c|c|c|c|c|c|c|c|}
\hline Yearly Income & In AUS \$ & $\mid \begin{array}{l}\text { Tax Exp on } \\
\text { Contribtion }\end{array}$ & $\begin{array}{l}\text { Tax Exp on } \\
\text { Returns }\end{array}$ & $\begin{array}{l}\text { Total Tax } \\
\text { Exp }\end{array}$ & $\begin{array}{l}\text { Total cont } \\
\text { tax paid }\end{array}$ & $\begin{array}{l}\text { Total inv } \\
\text { returns tax } \\
\text { paid }\end{array}$ & \begin{tabular}{|l|} 
Total Taxes \\
paid
\end{tabular} & \begin{tabular}{|l|} 
Super \\
accumuled \\
at 67
\end{tabular} & $\begin{array}{l}\text { Gross } \\
\text { Saving (GS) }\end{array}$ & $\begin{array}{l}\text { Total tax in } \\
\% \text { of GS }\end{array}$ & \begin{tabular}{|l|} 
Total tax \\
exp in \% of \\
GS
\end{tabular} & $\begin{array}{l}\text { Total tax } \\
\text { and tax exp } \\
\text { in \% of GS }\end{array}$ & $\begin{array}{l}\text { Net } \\
\text { Annuity } \\
\text { at } 67\end{array}$ & $\begin{array}{l}\text { Net } \\
\text { replace- } \\
\text { ment rate }\end{array}$ & $\begin{array}{l}\text { Avg tax } \\
\text { rate on } \\
\text { AN }\end{array}$ & $\begin{array}{l}\text { Total tax } \\
\text { on AN }\end{array}$ \\
\hline 0.5 of Average & $\$ 37500$ & $\$ 10961$ & $\$ 83353$ & $\$ 94314$ & $\$ 30459$ & $\$ 27149$ & $\$ 57608$ & $\$ 251738$ & $\$ 309346$ & $19 \%$ & $30 \%$ & $49 \%$ & $\$ 9682$ & $26 \%$ & $0 \%$ & $\$ 0$ \\
\hline 1.0 of Average & $\$ 75000$ & $\$ 71103$ & $\$ 187634$ & $\$ 258737$ & $\$ 60919$ & $\$ 54298$ & $\$ 115217$ & $\$ 503476$ & $\$ 618693$ & $19 \%$ & $42 \%$ & $60 \%$ & $\$ 19364$ & $26 \%$ & $0 \%$ & $\$ 0$ \\
\hline 2.0 of Average & $\$ 150000$ & $\$ 178756$ & $\$ 424663$ & $\$ 603419$ & $\$ 121838$ & $\$ 108596$ & $\$ 230434$ & $\$ 1006951$ & $\$ 1237385$ & $19 \%$ & $49 \%$ & $67 \%$ & $\$ 38728$ & $26 \%$ & $0 \%$ & $\$ 0$ \\
\hline
\end{tabular}

\section{Tax Regime TEE}

\begin{tabular}{|c|c|c|c|c|c|c|c|c|c|c|c|c|c|c|c|c|}
\hline Yearly Income & In AUS \$ & \begin{tabular}{|l|} 
Tax Exp on \\
Contribtion \\
\end{tabular} & \begin{tabular}{|l|} 
Tax Exp on \\
Returns \\
\end{tabular} & \begin{tabular}{|l} 
Total Tax \\
Exp
\end{tabular} & \begin{tabular}{|l} 
Total cont \\
tax paid
\end{tabular} & \begin{tabular}{|l} 
Total inv \\
returns tax \\
paid
\end{tabular} & \begin{tabular}{|l|} 
Total Taxes \\
paid
\end{tabular} & \begin{tabular}{|l|} 
Super \\
accumuled \\
at 67
\end{tabular} & $\begin{array}{l}\text { Gross } \\
\text { Saving (GS) }\end{array}$ & $\mid \begin{array}{l}\text { Total tax in } \\
\% \text { of GS }\end{array}$ & $\begin{array}{l}\text { Total tax } \\
\exp \text { in \% of } \\
\text { GS }\end{array}$ & $\begin{array}{l}\text { Total tax } \\
\text { and tax exp } \\
\text { in \% of GS }\end{array}$ & $\begin{array}{l}\text { Net } \\
\text { Annuity } \\
\text { at } 67\end{array}$ & $\begin{array}{l}\text { Net } \\
\text { replace- } \\
\text { ment rate }\end{array}$ & $\begin{array}{l}\text { Avg tax } \\
\text { rate on } \\
\text { AN }\end{array}$ & $\begin{array}{l}\text { Total tax } \\
\text { on AN }\end{array}$ \\
\hline 0.5 of Average & $\$ 37500$ & $\$ 0$ & $\$ 101926$ & $\$ 101926$ & $\$ 61771$ & $\$ 0$ & $\$ 61771$ & $\$ 239134$ & $\$ 300905$ & $21 \%$ & $34 \%$ & $54 \%$ & $\$ 9197$ & $25 \%$ & $0 \%$ & $\$ 0$ \\
\hline 1.0 of Average & $\$ 75000$ & $\$ 0$ & $\$ 205064$ & $\$ 205064$ & $\$ 142526$ & $\$ 0$ & $\$ 142526$ & $\$ 444167$ & $\$ 586693$ & $24 \%$ & $35 \%$ & $59 \%$ & $\$ 17083$ & $23 \%$ & $0 \%$ & $\$ 0$ \\
\hline 2.0 of Average & $\$ 150000$ & $\$ 0$ & $\$ 422302$ & $\$ 422302$ & $\$ 315838$ & $\$ 0$ & $\$ 315838$ & $\$ 838240$ & $\$ 1154078$ & $27 \%$ & $37 \%$ & $64 \%$ & $\$ 32240$ & $21 \%$ & $0 \%$ & $\$ 0$ \\
\hline
\end{tabular}

\section{Tax Regime EET}

\begin{tabular}{|c|c|c|c|c|c|c|c|c|c|c|c|c|c|c|c|c|}
\hline Yearly Income & In AUS \$ & \begin{tabular}{|l|} 
Tax Exp on \\
Contribtion \\
\end{tabular} & \begin{tabular}{|l|} 
Tax Exp on \\
Returns \\
\end{tabular} & \begin{tabular}{|l} 
Total Tax \\
Exp \\
\end{tabular} & $\begin{array}{l}\text { Total cont } \\
\text { tax paid }\end{array}$ & \begin{tabular}{|l} 
Total inv \\
returns tax \\
paid
\end{tabular} & $\begin{array}{l}\text { Total Taxes } \\
\text { paid }\end{array}$ & \begin{tabular}{|l} 
Super \\
accumuled \\
at 67
\end{tabular} & $\begin{array}{l}\text { Gross } \\
\text { Saving (GS) }\end{array}$ & $\begin{array}{l}\text { Total tax in } \\
\% \text { of GS }\end{array}$ & $\begin{array}{l}\text { Total tax } \\
\exp \text { in \% of } \\
\text { GS }\end{array}$ & $\begin{array}{l}\text { Total tax } \\
\text { and tax exp } \\
\text { in } \% \text { of GS }\end{array}$ & $\begin{array}{l}\text { Net } \\
\text { Annuity } \\
\text { at } 67\end{array}$ & $\left|\begin{array}{l}\text { Net } \\
\text { replace- } \\
\text { ment rate }\end{array}\right|$ & $\begin{array}{l}\text { Avg tax } \\
\text { rate on } \\
\text { AN }\end{array}$ & $\begin{array}{l}\text { Total tax } \\
\text { on AN }\end{array}$ \\
\hline 0.5 of Average & $\$ 37500$ & $\$ 41420$ & $\$ 142100$ & $\$ 183520$ & $\$ 0$ & $\$ 0$ & $\$ 0$ & $\$ 339248$ & $\$ 339248$ & $0 \%$ & $54 \%$ & $54 \%$ & $\$ 13048$ & $35 \%$ & $0.0 \%$ & $\$ 0$ \\
\hline 1.0 of Average & $\$ 75000$ & $\$ 132021$ & $\$ 313847$ & $\$ 445868$ & $\$ 0$ & $\$ 0$ & $\$ 0$ & $\$ 678495$ & $\$ 678495$ & $0 \%$ & $66 \%$ & $66 \%$ & $\$ 24595$ & $33 \%$ & $5.8 \%$ & $\$ 39019$ \\
\hline 2.0 of Average & $\$ 150000$ & $\$ 300594$ & $\$ 703605$ & $\$ 1004199$ & $\$ 0$ & $\$ 0$ & $\$ 0$ & $\$ 1356990$ & $\$ 1356990$ & $0 \%$ & $74 \%$ & $74 \%$ & $\$ 43681$ & $29 \%$ & $16.3 \%$ & $\$ 221275$ \\
\hline
\end{tabular}


The estimations offer a rich information set with the key results as follows:

$>$ Using the existing tax structure without any preferences as TTE benchmark would amount to huge tax payments, with the accumulated taxes are around 50 percent of gross savings ( 44.2 percent for half, and 53.5 percent for the double of average income).

$>$ The Australian tax scheme offers some preferences for contributions and investment returns and leaves disbursement untaxed $\left(T^{*} T^{*} E\right)$. This results in main tax expenditure and reduces the taxes paid to less than half compared to the TTE benchmark. The total taxes paid in percent of gross saving are reduce to 19 percent across the income strata.

$>$ A front-loaded TEE regime would increase the taxes paid on gross savings compared to the current $T^{*} T^{*} E$ taxation to 21,24 and 27 percent, respectively. A back-loaded EET regime would, be definition eliminate any taxes on gross saving as only annuities are taxed.

$>$ As a result of the different taxation approach, the net replacement rate is the lowest under the TTE and the highest under the EET approach, with both $T^{*} T^{*} E$ and TEE somewhere in the middle and not too different. Under an EET scheme, those with half of average income would remain untaxed, average income earner lightly taxed (5.8 percent) and even those with double of average income have an average tax rate on the annuity of only 16.3 percent.

$>$ The results indicate that an actual tax system, such as the Australian, is quite different from comprehensive income or back-loaded consumption-type tax system while it is close to a front-loaded one in tax revenue and income replacement effects. It also makes the point that under a progressive income tax structure front- and back-loading of tax preferences lead to quite different results: In fiscal and redistributive terms TEE is not equal EET.

\section{v. Benefits of proposed approach and conceptual issues}

We end this Section by highlighting key benefits of the proposed TEE approach with deferred tax payment and by indicating also a few conceptual issues that need further exploration.

We see the key benefits in the following three characteristics:

$>$ The recording of taxes due but deferred, but also the taxes already paid, and the net amount of savings accumulation across the life cycle of an individual offers very useful transparency on tax expenditure, revenue claims, and revenue received and thus also about the fiscal distribution across individuals and groups. This is useful even in absence of portability considerations but crucial if fiscal fairness across individuals and countries should be established.

> The information recorded and shared between countries would greatly facilitate the establishment and periodic review and adjustment of bi-lateral social security agreements as well as bi-lateral double-taxation treaties. Without this information it will be essentially impossible to establish how much tax revenues are at stake, how much have been deferred and how many can be expected and thus guide negotiations and decisions.

$>$ The availability of the data at national level would allow an easier assessment of gross vs net implicit public pension liabilities. By 2017 the EU will have all member countries publish data on (gross) implicit pension liabilities as SNA satellite' accounts. Currently 
only gross liabilities are known (and one simple and dated country study from the early 1990s). The revenue content of pension claims/liabilities gains importance with aging populations.

For the reliable estimation of individual and national (deferred and paid) revenue data, a number of conceptual and operational issues will need further elaboration, including:

$>$ How to calculate and assign the actual or deferred taxes on employers' mandated or voluntary retirement savings contributions? In most countries part of the contribution and saving efforts for individuals is financed by employers that often but not always can deduct the related expenditures from their corporate or personal income tax. For fair comparison across individuals this requires assumptions on how the employers' contributions and tax incidence affects the individual and this may vary across sectors.

$>$ A comparison across individuals of their taxes over the life-cycle requires the application of appropriate rates for discounting and compounding. Should the choice rely on realized rates with implications for estimates' variability in face rate fluctuations? Or should it better rely on derived steady-state rates? Should there be differences in the rates for unfunded and funded schemes and their rates of return. Or should the discount rate no better reflect the risk of income streams and not the risk of the matching assets?

$>$ Which convention should be applied to calculate deferred tax/granted tax exemption by benefit type and tax treatment? How to slice-in the deductions for contributions and returns?: Upstream from mandated and unfunded to voluntary and funded provisions, or reverse? Or proportionate to amount accumulated in a specific year?

\section{Summary and Next Steps}

There is a strong need of strengthening the analytical foundations of the taxation of pensions in a world of population aging, globalization of capital and labor, and a rising share of individuals spending at least some part of their working life abroad and acquiring pension rights.

Currently, there is limited analytical guidance on the taxation of retirement provisions within a country, and there is none for the taxation of internationally portable pensions. For both national and international taxation of pensions, the actual taxation approaches are characterized by a high level of diversity, complexity and inconsistency within and across countries that risk harming labor mobility and creating fiscal unfairness.

The proposed taxation approach for internationally portable pensions mixes notional frontloaded taxation (as the tax due on contributions/savings is deferred) with actual back-loaded taxation as the taxes are due when the benefits are disbursed (in source or residency country) or when accumulated savings effectively leave the country. This approach promises to establish broadly neutrality for international labor mobility decisions, fiscal fairness of tax revenue around retirement provisions between source and residency country, and bureaucratic efficacy, including a consistency with EU regulations and most double-taxation treaties.

Yet the proposed approach is quite likely only the beginning of a long journey as many conceptual and operational issues need further elaboration, and other and more convincing approaches may be brought to the table. Overall, it seems important to think innovatively and jointly about a tax cum pension system that aligns the life-cycle approach of pensions with a life-cycle treatment of taxation, at least for retirement purposes and perhaps beyond. 


\section{References}

Atkinson, Anthony and Joseph Stiglitz. 1976. "The design of tax structure: direct versus indirect taxation." Journal of Public Economics 6 (1-2): 55-75.

Auerbach, Alan. 2009. "Direction in Tax and Transfer Theory." in Melbourne Institute, ed.

Australia's Future Tax and Transfer Policy Conference: Proceedings of a Conference, University of Melbourne, Chapter 4: 63-71.

Chomik, Rafal and John Piggott. 2015. "Re-examining tax expenditure." Presentation at the $2^{\text {nd }}$ CESifo-CEPAR Workshop on the Taxation of Pensions, Munich, September 3 and 4, 2015 (forthcoming).

Deutsche Rentenversicherung. Rentenstand am 31.12.2014. Berlin

Diamond, Peter. 2011. "Economic Theory and Tax and Pension Policies." The Economic Record 87: 2-22.

Eurostat. 2015. Stiatiscs explained: Migration and migrant population statistics. http://ec.europa.eu/eurostat/statisticsexplained/index.php/Migration and migrant population statistics Holzmann, Robert. 2015, forthcoming. "Do Bilateral Social Security Agreements Deliver on the Portability of Pensions and Health Care Benefits? A Summary Policy Paper on Four Migration Corridors Between EU and Non-EU Member States," Washington, DC.: World Bank.

Genser, Bernd and Robert Holzmann. 2015. "The Taxation of Internationally Portable Pensions: Everything goes, for what reason, and with some possible solutions." Presentation at the $2^{\text {nd }}$ CESifo-CEPAR Workshop on the Taxation of Pensions, Munich, September 3 and 4, 2015 (forthcoming).

Holzmann, Robert, and Johannes Koettl. 2015. "Portability of Pension, Health, and Other Social Benefits: Facts, Concepts, and Issues." CESifo Economic Studies 61 (2): 335-345 (first published online May 9, 2015 doi:10.1093/cesifo/ifv009).

Holzmann, Robert and Martin Werding. 2015. "Portability of Social Benefits: Research on a Critical Topic in Globalization," CESifo Economic Studies 61 (2): 335-345 (first published online May 9, 2015 doi:10.1093/cesifo/ifv009)

Holzmann, Robert and Edward Palmer. 2013, eds. NDC Pension Schemes in a Changing Pension World, Volume 2: Gender, Politics, and Financial Stability. DC: The World Bank. . 2012, eds. NDC Pension Schemes in a Changing Pension World, Volume 1:

Progress, Issues, and Implementation. DC: The World Bank. . 2006, eds. Pension Reform: Issues and Prospect for Non-Financial Defined Contribution (NDC) Schemes.

Holzmann, Robert und Richard Hinz. 2005. Old-Age Income Support in the 21st Century: An International Perspective on Pension Systems and Reform. Washington, DC: The World Bank. 
Holzmann, Robert, Johannes Koettl and Taras Chernetsky. 2005. "Portability Regimes of Pension and Health Care Benefits for International Migrants: An Analysis of Issues and Good Practices", Social Protection Discussion Paper, No 0519. Washington, DC: World Bank.

Published 2006, Global Migration Perspectives. Geneva: Global Commission on International Migration.

Institute for Fiscal Studies. 1978. "The structure and reform of direct taxation", London: Allen and Unwin.

Lee, Ronald and Andrew Mason. 2011. POPULATION AGING AND THE GENERATIONAL ECONOMY: A Global Perspective. Edward Elgar.

Meier, Volker and Andreas Wagener. 2015. "Do Mobile Pensioners Threaten the Deferred Taxation of Savings?" CESifo Economic Studies 61 (2): 465-483 (first published online May 31, 2014 doi:10.1093/cesifo/ifu020)

Wellisch, Diemar, Sven-Oliver Lenz, Kerstin Tiele, and Rasmus Gahl. 2008. Besteuerung der Altersvorsorge: Ein internationaler Vergleich. Baden-Baden: Nomos.

Werding, Martin, and Stuart McLennan. 2015. "International Portability of Health-Cost Cover: Mobility, Insurance, and Redistribution." CESifo Economic Studies 61 (2): 484-519 (first published online June 18, 2014 doi:10.1093/cesifo/ifu022)

Kaldor, Nicholas. 1955. An Expenditure Tax. London: Allen and Unwin.

Robalino, David, Edward Whitehouse, Anca Mataoanu, Alberto Musalem, Elisabeth Sherwood, and Oleksiy Sluchynsky. 2005. "Tax treatment of pension systems. In: Pensions in the Middle East and North Africa. Time for change." The World Bank, Orientations in Development Series. Washington, D.C.: The World Bank, 211-216.

Romaniuk, Katarzyna. 2013. Pension fund taxation and risk-taking: should we switch from the EET to the TEE regime? Annals in Finance 9: 573-588 (DOI 10.1007/s10436-012-0204-3)

United Nations. 2015. World Population Prospects: Key findings and advance tables. 2015 Revision. New York: Department of Economics and Social Affairs - Population Division. http://esa.un.org/unpd/wpp/

US Department of Treasury. 1977. Blueprints for basic tax reform. Washington, DC: US Government Printing Office.

Wellisch, Diemar, Sven-Oliver Lenz, Kerstin Tiele \& Rasmus Gahl. 2008. Besteuerung der Altersvorsorge: Ein internationaler Vergleich. Baden-Baden: Nomos

Whitehouse Edward. 1999. The Tax Treatment of Funded Pensions." Social Protection Discussion Paper Series No. 9910, April. Washington, DC: The World Bank.

Yoo, Kwang-Yeol, and de Serres, Alein. 2004. Tax Treatment of Private Saving in OECD Countries. OECD Economic Studies 39, 73-110. 